\title{
Definition of the Frasnian/Famennian Stage boundary
}

The boundary for the Frasnian/Famennian Stage Global Stratotype Section and Point (GSSP) has been ratified by ICS and IUGS and is drawn in a section exposed near the Upper Coumiac Quarry in the southeastern Montagne Noire, France. The position of the boundary was selected by the Subcommission on Devonian Stratigraphy in 1991 to coincide with the lower boundary of the Lower Palmatolepis triangularis Zone in the conodont biostratigraphy. The revised definition of the lower boundary of the zone, proposed herein, excludes the extremely rare occurrences of Palmatolepis triangularis a few centimetres lower, within the uppermost conodont zone. The GSSP also coincides with the boundary between the Crickites holzapfeli Zone and the Phoenixites frechi Zone in the goniatite scale. The position of the GSSP is immediately above a major horizon of extinction within the Devonian and is stratigraphically somewhat lower than formerly used boundary levels for the base of the Famennian.

\section{Introduction}

Historically, several different levels have been used to define the base of the Famennian. In the type area for the naming of the stages in southern Belgium, precise documentation in recent years has been given to a new reference section replacing the now-infilled classic section in the Senzeilles railway cutting (Bultynck and others, 1988). Largely resulting from work in the first quarter of this century in Germany, another boundary was used that was based on the entry of the goniatite Cheiloceras in the pelagic realm. In the latter half of this century the considerable growth of conodont studies has led to much refinement of the biostratigraphy. However, the level taken as the base of the Famennian has varied between a level at the base of the crepida Zone down to the base of the Lower triangularis Zone. The need for an international definition has become urgent. The Subcom-

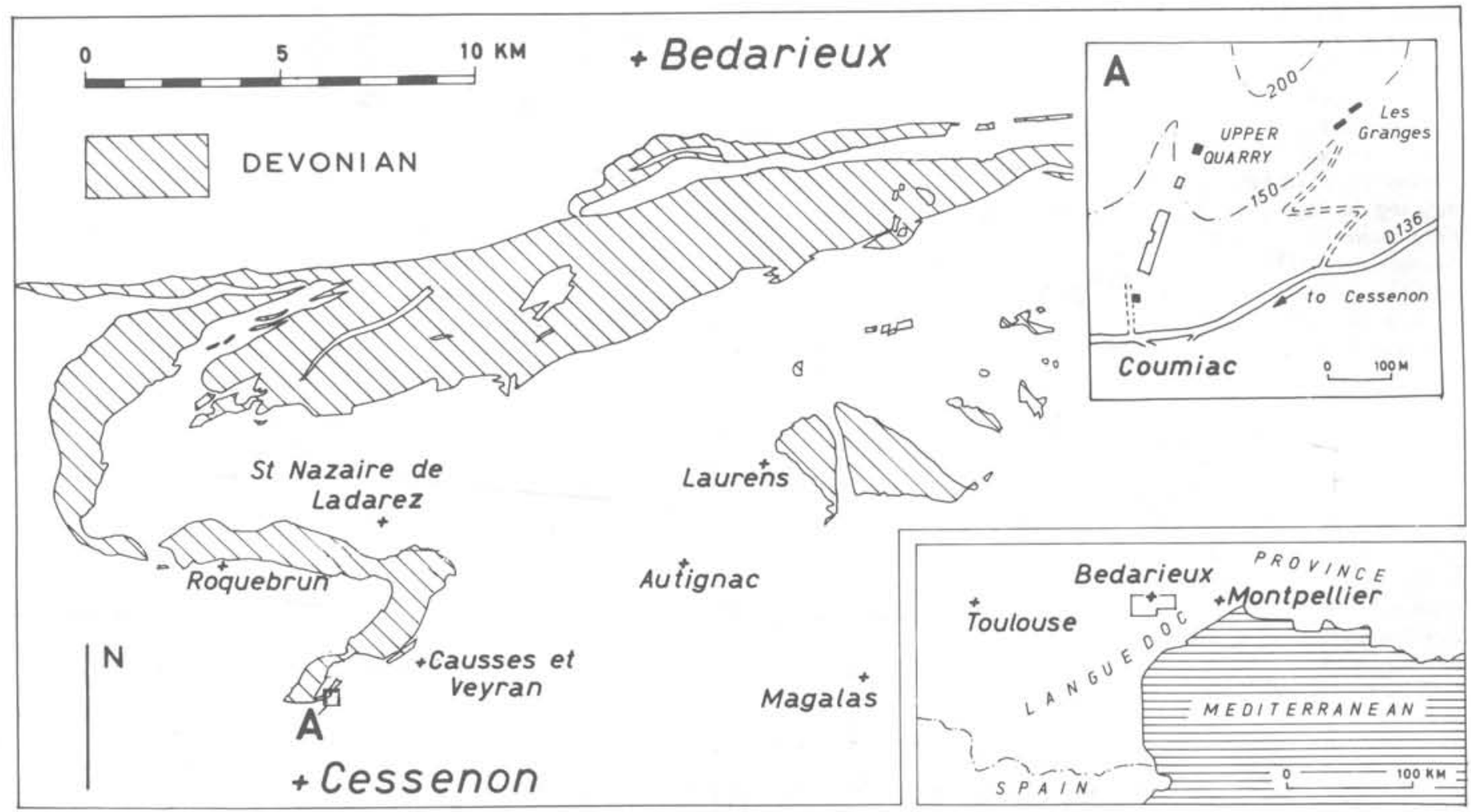

Figure 1 Maps showing the position of the Montagne Noire in southeastern France and of the Upper Coumiac Quarry near Cessenon, the site of the Global Stratotype Section and Point (GSSP) for the definition of the base of the Famennian Stage (inset map A). Modified from Becker and others (1989). 
mission on Devonian Stratigraphy (SDS) has given careful consideration to which level is most appropriate for international correlation and it decided, at a meeting in Washington in 1989, that a GSSP should be sought in relation to the base of the Lower triangularis conodont Zone. Final ballots and ratification by ICS and IUGS (in January 1993) led to a level in a section at Coumiac, southern France being designated as the Global Stratotype Section and Point (GSSP). A brief review of the documentation leading to this decision is given here. The conodont and goniatite biostratigraphic divisions are shown in figures 5 and 6.

It has been recognised by the Subcommission that, in general, Devonian sections in pelagic realm facies are more likely to be complete than those in the neritic facies. The pelagic facies forms a better basis for the biostratigraphical precision needed for international correlation. In particular the conodont and goniatite records are better in those facies. That is not to imply that there are not facies rich in other groups, for example spores and brachiopods, which are very important for correlation, but it is normally easier to correlate into such sections secondarily from primary sections in the pelagic facies. In the last resort the Subcommission concentrated on two such sections, one at Steinbruch Schmidt in the Rhenish Slate Mountains, Germany (Sandberg and others, 1990; Schindler, 1990) and the other at Coumiac in the Montagne Noire (Feist, 1990). The latter was finally selected because of the better documentation of macrofossil groups.

\section{Recommended stratotype}

The recommended boundary GSSP between the Frasnian and Famennian Stages (Devonian) is above the Upper Coumiac Quarry, near Cessenon, Montagne Noire, France (figure 1). The section is situated in the southeastern Montagne Noire, Départment Hérault, District of Cessenon (topographic sheet 1:25 000, No. 2544 E, Murviellès-Béziers; Lambert's coordinates: $\mathrm{x}=130375, \mathrm{y}=65855$ ). It is adjacent to the southeastern border of the disused upper marble quarry (UQ) of Coumiac, $175 \mathrm{~m}$ WSW of the Les Granges farmhouse, about $1.5 \mathrm{~km}$ NE of Cessenon village and $2100 \mathrm{~m}$ SW of Causses et Veyran. It can be reached easily by a path up the hill from near the track to Les Granges farmhouse from the road DI36 between Cessenon and St Nazaire-de-Ladarez. The ground is owned by the commune of Cessenon and is already protected as part of a water supply area. Conservation and protection of the section has been assured by communal and department officials. Free access for scientists is confirmed.

The sequence is one of pelagic calcilutites, mostly red tinted and well bedded, with bedding probably controlled by Milankovitch-Band climatic oscillations during sedimentation. The sequence has been described in published accounts (House and others, 1985; Klapper, 1989; Becker and others, 1989; Schindler 1990; Becker 1993a) and is depicted in figure 2. The boundary is drawn between Beds $31 \mathrm{~g}$ and $32 \mathrm{a}$ as shown in figures 2 and 3. Distinctive is Bed $31 \mathrm{~g}$ which is correlated with the Upper Kellwasser Limestone of Germany and which is a hypoxic dark grey calcilutite to calcarenite above which is the most marked faunal boundary. Both Beds $31 \mathrm{~g}$ and $32 \mathrm{a}$ are characterized by pelagic faunas.

The sequence chosen shows a complete succession through the early Frasnian to late Famennian. It is unfaulted and has no tectonic problems. The beds are approximately vertical. Equivalent sections can be found elsewhere in the area. The rocks are of low-grade metamorphism and thermal maturity (CAI 2-3) and comprise an homogeneous pelagic calcilutite sequence without marly or shaly interbeds. There is a complete zonal succession with a rich fossil content, especially of the biostratigraphically significant groups of conodonts, ammonoids, trilobites, tentaculites and ostracods. Detailed documentation has been provided of this (Feist, 1990). Geochemical work across the boundary at Coumiac has also been published (Goodfellow and others, 1989; Grandjean and others, 1989; Grandjean-Lécuyer and others, 1993; Joachimski and Buggisch, 1993; Girard and others, 1993) and currently other investigations are being

\section{Figure 2 Detailed map of the Upper Quarry at Coumiac, near Cessenon, showing the bed numbering and the position of the GSSP defining the base of the Famennian between Beds 31 and 32. Modified from House and others (1985).}

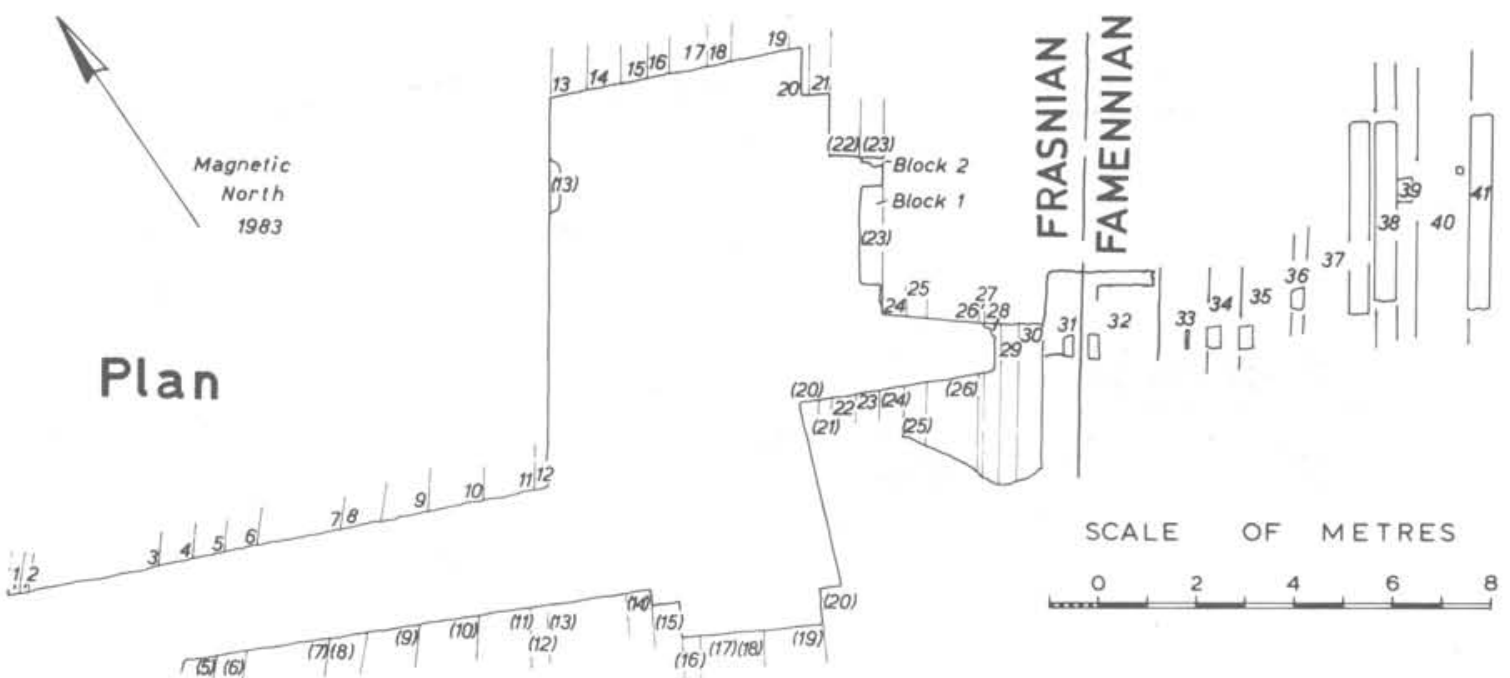

Figure 3 The detailed succession of beds around the GSSP level between beds $31 \mathrm{~g}$ and $32 a$ above the Upper Coumiac Quarry near Cessenon.

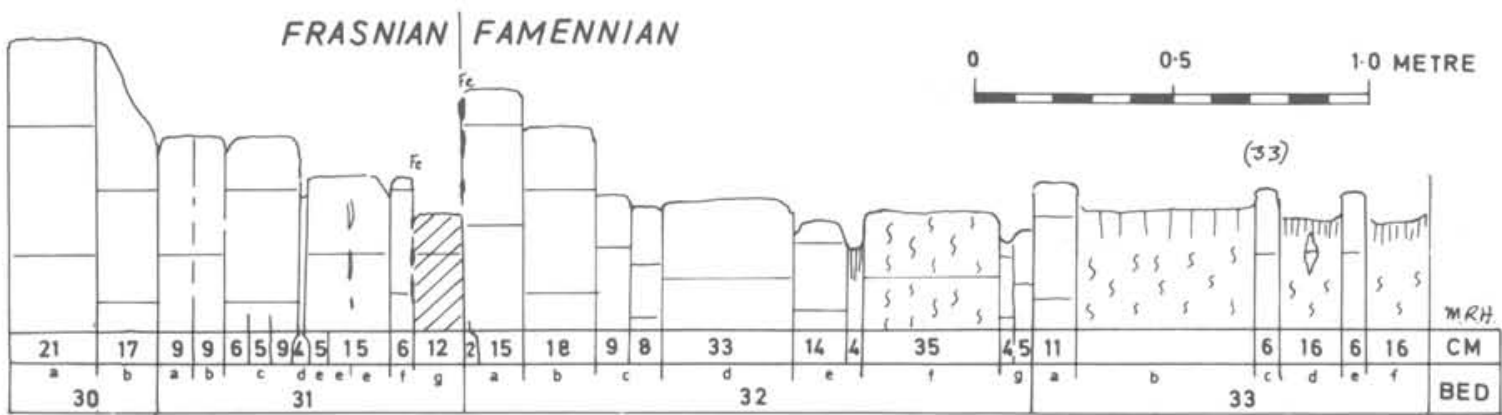


undertaken. Magnetostratigraphic work indicates that the area was remagnetized during the Permian.

\section{Correlation of the proposed boundary level}

The boundary level proposed represents perhaps the best correlated horizon in the Devonian. A review of more than 30 international sections has been presented by Sandberg and others (1988) including localities in North America and Europe. Further correlation is established in North Africa (Becker and others 1988), China (Ji, 1989) and Australia (Becker and others, 1991). The boundary corresponds to the extinction of all species of the conodonts Ancyrodella and Ozarkodina and the loss of all but a few species of Palmatolepis, Polygnathus, and Ancyrognathus, according to Sandberg and others (1988, pp. 293-294). There is a well-known extinction among goniatites of the Gephuroceratidae and Beloceratidae and the record for both conodonts and goniatites at Coumiac demonstrates this well. The last of the brachiopod Atrypidae occurs just below the boundary level (Becker and others, 1991). Among trilobites the Dalmanitidae, Odontopleuridae, Harpetidae and Aulacopleurinae all disappear at the base of the end-Frasnian Upper Kellwasser Limestone level of Bed 31g. Others have documented the global extinction of coral (Sorauf and Pedder, 1986; Scrutton, 1988), stromatoporoid (Stearn, 1987) and acritarch (Vanguestaine and others, 1983) groups and there has been much recent local documentation in many areas. A changeover of benthonic ostracod faunas across the boundary at Coumiac has been published (Lethiers and Feist, 1991).

\section{Conodont record}

The conodont sequence at the Upper Coumiac Quarry extends from within the middle part of the Frasnian across the Frasnian/Famennian boundary and into the lower Famennian (as high as the Upper crepida Zone in the current sampling up to Bed 44). Upper Coumiac is a key sequence for the thirteen-fold Montagne Noire Frasnian zonation (Klapper 1989), substantial parts of which have been replicated at various sections in North America, Western Australia, and European Russia (Klapper and Foster 1993, figure 2). The sequence at Upper Coumiac extends from Frasnian Zone 5 to the top of Zone 13 (= top of the Frasnian), but only the higher part of the Frasnian sequence is of concern here.

Bed 24a, the Lower Kellwasser Limestone, has the lowest occurrence of Ancyrognathus asymmetricus, which is the defining species for the lower boundary of the Upper gigas Zone in the zonation of Ziegler (1962, p.23; 1971). The conodont fauna of Bed 24a is interpreted as the highest sampled level of Montagne Noire Zone 12 (Klapper, 1989, p. 456, figure 4). However, due to the facies of the Lower Kellwasser at Coumiac, which apparently resulted in the extreme rarity of Palmatolepis in Bed 24a, a higher zonal identification cannot be excluded. Nonetheless, the lower boundary of Zone 13 is necessarily taken at the lowest occurrence of Palmatolepis bogartensis in Bed 24e (figure 5), as well as at the coincident lowest occurrence of $\mathrm{Pa}$. hassi s.s. The lowest occurrence of $\mathrm{Pa}$. rhenana sensu Klapper and Foster (1993, p. 24, figure 2) is high within Zone 13 in Bed $30 \mathrm{~b}$, coincident with the lowest $P a$, boogaardi (figure 5).

It is noteworthy that species characteristic of the higher part of the Frasnian at Upper Coumiac, Palmatolepis bogartensis, Pa. winchelli, $\mathrm{Pa}$. rhenana, $\mathrm{Pa}$. boogaardi, Ancyrognathus asymmetricus, and Ancyrodella curvata all terminate in either Beds $31 \mathrm{f}$ or $31 \mathrm{~g}$. The conodont fauna of Bed 31g, the Upper Kellwasser Limestone, has all but two of the foregoing species (figure 5) and is dominated in terms of its Palmatolepis component, by $\mathrm{Pa}$. bogartensis and $\mathrm{Pa}$. winchelli. On evidence of the lowest (and only) occurrence of Ancyrognathus ubiquitus in Bed $31 \mathrm{~g}$, the fauna is apparently correlative with the upper part of the linguiformis Zone (Ziegler and Sandberg, 1990 , p. 21), despite the absence of Pa. linguiformis. In the Montagne Noire Frasnian zonation, Bed $31 \mathrm{~g}$ represents the highest part of Zone 13. Ancyrognathus ubiquitus also occurs in faunas of the Upper Kellwasser Limestone at three other nearby Montagne Noire localities: Causses et Veyran North and South, and Lower Coumiac (Feist, 1990, pp. 19, 24, 30). All these faunas are correlative with the linguiformis Zone, but lack the nominal species (Becker and others, 1989 , pp. 262, 265).
Figure 4

Photograph of the succession above the Upper Coumiac Quarry. The GSSP lies between Bed $31 \mathrm{~g}$ and $32 a$. For scale compare with the profile of the beds given in figure 3 .

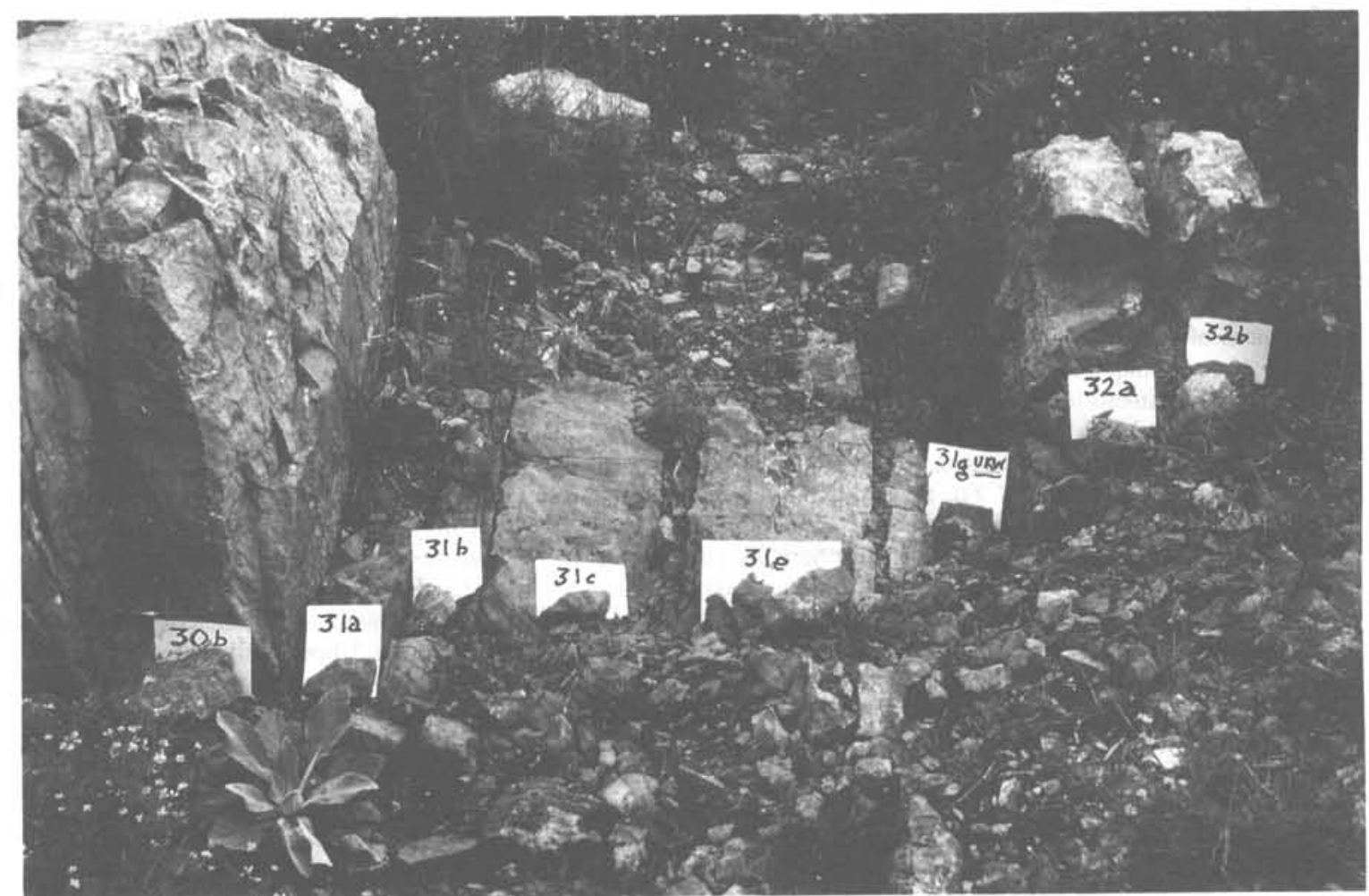


Figure 5 Range chart of conodont species across the Frasnian/Famennin boundary at Upper Coumiac Quarry. The GSSP for the base of the

Famennian is at the base of Bed 32a. Position of the upper part of Frasnian Zone 12, Frasnian Zone 13 (Klapper, 1989), the Lower, Middle and Upper triangularis Zones, and the Lower and Middle crepida Zones is indicated. Recognition of the Lower, Middle and Upper crepida Zones is cited in the text, but species ranges are not shown above Bed 36.

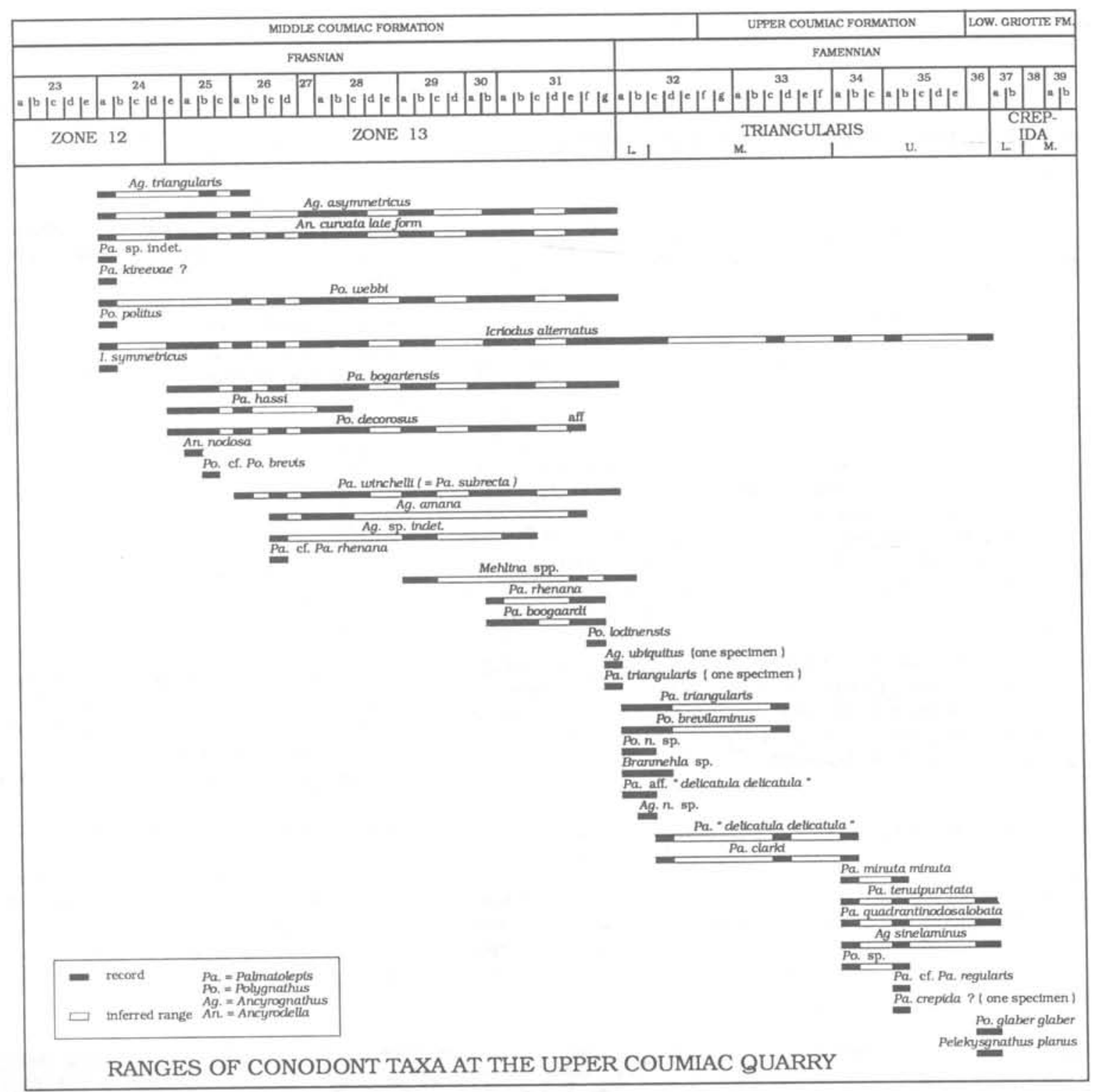

Upper Coumiac Bed 31g is also noteworthy in having one confidently identified specimen of Palmatolepis triangularis (and one questionable specimen of the same species, the former listed in Feist, 1990 , p. 36) among the many examples of $\mathrm{Pa}$. bogartensis and $\mathrm{Pa}$. winchelli. Although one cannot completely exclude the possibility of stratigraphical leak from the overlying Famennian, extremely rare occurrences of Palmatolepis triangularis in the uppermost Frasnian are probably not unique to the Upper Coumiac Quarry. The report of 27 unfigured specimens identified as $\mathrm{Pa}$. praetriangularis from three samples within Bed 16 of the Upper Kellwasser Limestone at Steinbruch Schmidt (Sandberg and others, 1988, Table 1) may represent another Frasnian occurrence of $P a$. triangularis. This inference is based on Klapper's study in 1990 of the holotype and two paratypes of $P a$. praetriangularis Ziegler and Sandberg (in Sandberg and others, 1988 , p. 304, pl. 1, figures 1, 3, 4), all from the highest bed of the linguiformis Zone at Hamar Laghdad, southern Morocco. These three types (Pa elements) have an arched outer-posterior platform, which gently rises from the lobe to just before the tip, then arches downward. This is exactly the same as in many specimens of $\mathrm{Pa}$. triangularis in the Lower and Middle triangularis Zones; however, in the holotype (Sannemann, 1955, pl. 24, figure 3) the outer posterior platform rises more steeply from the lobe to just before the tip, then arches downward. Consequently, the view is favoured here that Palmatolepis triangularis and $\mathrm{Pa}$. praetriangularis are synonyms. A slightly different view perhaps could be supported in which the latter is treated as an intraspecific morphotype, which is apparently a common form of $\mathrm{Pa}$. triangularis in the Lower triangularis Zone. Forms like the holotype of Sannemann seem to be relatively rare in this zone at least in the Montagne Noire. Clearly the praetriangularis morphotype crosses the Frasnian/Famennian boundary at Schmidt Quarry, as was well documented by Sandberg and others (1988, Table 1). [The 27 specimens listed as $\mathrm{Pa}$. praetriangularis in Bed 16 at Schmidt Quarry occur with 3380 listed as $P a$. subrecta (a junior synonym of $\mathrm{Pa}$. winchelli, see Klapper and Foster, 1993, but specimens of $\mathrm{Pa}$. bogartensis may have been included in this count)]. Thus, extremely rare $P a$. triangularis as this species is delimited here may occur slightly below the level of the lower boundary of the Lower triangularis Zone at both Coumiac and Schmidt quarries (up to 12 and $10 \mathrm{~cm}$ below the boundary, respectively). In both instances, this is within the context of the dominant upper Frasnian fauna of the Upper Kellwasser Limestone. Palmatolepis triangularis does not occur in the beds equivalent to Bed $31 \mathrm{~g}$ at the other Montagne Noire localities cited previously.

It follows, from the foregoing discussion, that there should be modification of the definition of the lower boundary of the Lower triangularis Zone (Ziegler, 1962, p. 25; Ziegler and Sandberg, 1990 , p. 22) for which the sole criterion is the first occurrence of the nominal taxon. Instead it is proposed here to use for definition the 
abundant or flood occurrence of Palmatolepis triangularis, to the virtual exclusion of other species of the genus, stratigraphically above the fauna dominated by the characteristic upper Frasnian species. These include Palmatolepis winchelli, Pa. bogartensis, $\mathrm{Pa}$. rhenana, Pa. boogaardi, Ancyrognathus asymmetricus, Ancyrodella curvata (late form), and in some areas, $P a$. linguiformis and $P a$. juntianensis. Thus, in the three sampling intervals within Bed 32a at Upper Coumiac (Feist, 1990, p. 36) and Bed 32b, Pa. triangularis is the only Palmatolepis species with the exception of transitional specimens here termed $P a$. aff. 'delicatula delicatula'. None of the species in Beds 31 and lower at Upper Coumiac (figure 5) ranges above the GSSP positioned at the lower boundary of Bed $32 \mathrm{a}$, except Icriodus alternatus, which is well known to cross the Frasnian/Famennian boundary elsewhere [the designation Mehlina spp. represents several species whose demarcation is unclear]. The new species of Ancyrognathus in Bed 32b is part of the Famennian lineage including $\mathrm{Ag}$. sinelaminus and $\mathrm{Ag}$. cryptus and is morphologically distinct from the main Frasnian Ancyrognathus lineages that include Ag. asymmetricus and Ag. ubiquitus. Characteristic upper Frasnian species of Polygnathus, such as Po. webbi and Po. decorosus, do not range above the GSSP and are replaced by $P o$. brevilaminus and Po. $\mathrm{n}$. sp. above the boundary at Coumiac.

The lower boundary of the Middle triangularis Zone, defined by the lowest occurrence of Palmatolepis clarki and $\mathrm{Pa}$. delicatula delicatula (Ziegler, 1962, p. 26; 1971, chart 5), is at the base of Upper Coumiac Bed 32c. The former species is perfectly useable for defining the base of the zone and that part of the original definition is followed here. But use of the latter taxon is clouded by a taxonomic problem. That is, $\mathrm{Pa}$. delicatula delicatula in the sense of most authors since 1962, and Pa. delicatula platys of Ziegler and Sandberg (1990), are characterized by platform outlines of the Pa element distinctly different from that of the lectotype of Pa. delicatula Branson and Mehl (1934, pl. 18, figure 4; a new photograph in a non-oblique view is available from GK on request). As the solution of this problem cannot be treated fully in this paper, the name of specimens corresponding to $\mathrm{Pa}$. delicatula delicatula (sensu auct.) in Upper Coumiac Beds $32 \mathrm{c}$, $33 \mathrm{c}$, and $34 \mathrm{a}$ is written in quotation marks.

Figure 6 Range chart of succession of goniatites so far recorded from Bed 23 to Bed 39 in the section around the GSSP above the Upper Coumiac Quarry, with the assignment of ammonoid zones. For correlation with the conodont zonation, see figure 5.
Recognition of the Upper triangularis Zone (Beds 34a, 35a, 36 ), the Lower crepida Zone (Bed 37, on the unquestioned occurrence of the nominal species), and Middle crepida Zone (Beds $41-44$ ) is straightforward, but not especially pertinent to the description of the GSSP.

\section{Goniatite record}

Coumiac is one of the few known places with a continuous goniatite succession from the Middle Frasnian to the Middle Famennian. Ammonoids occur both in the latest Frasnian (Bed 31g) and basalmost Famennian (Bed 32a). Preservation, however, is in many cases relatively poor, extraction tedious, and species-level determination is often difficult. The faunal record (figure 6 ) has gradually been built up over the past several years and certainly can be further extended. Bedby-bed investigations were first conducted by House and others (1985) and updates of faunal lists were supplied in consecutive years to SDS and later summarised (in Feist, 1990). A detailed description of the Famennian part is provided in Becker (1993a).

The boundary itself is clearly marked by the disappearance of the gephuroceratids and beloceratids with the immediate subsequent bloom of the tornoceratid Phoenixites frechi in the haematiteenriched base of Bed $32 \mathrm{a}$, but the species is known to occur in late Frasnian beds elsewhere (Becker, 1993a). The frechi (partial range) Zone or Phoenixites Genozone (do II-A) is followed in Bed 35c by the entry of first Falcitornoceras and questionable cross-sections of Cheiloceras. Both genera are defining forms of the do II-B. Undoubted Cheiloceras specimens have not been collected below Bed 39 and earliest falcitornoceratids (especially those found in Bed 36 ) are still somewhat intermediate to Phoenixites.

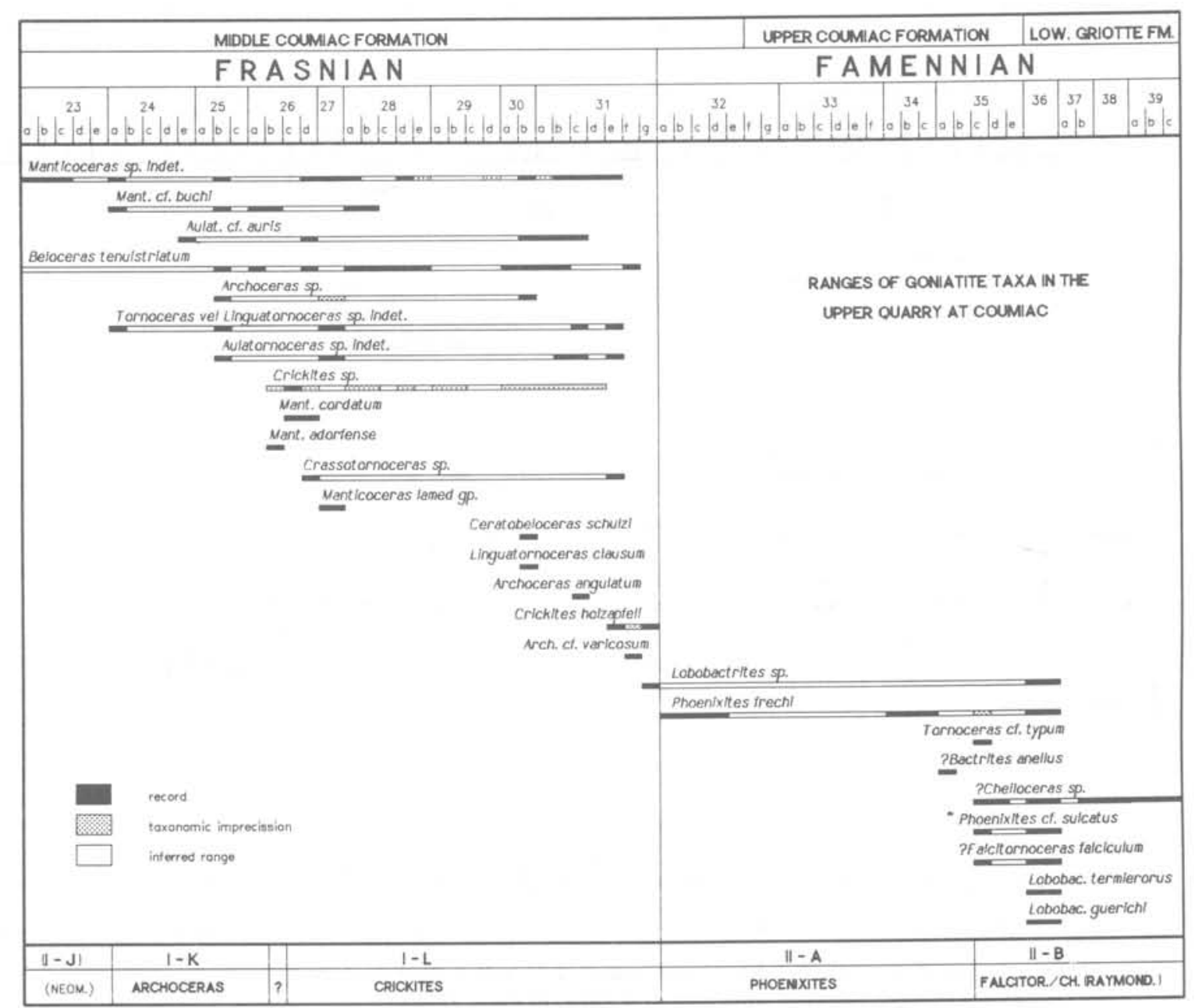


The Coumiac goniatite sequence generally matches faunal successions described from classical sections of the Rhenish Slate Mountains and Thuringia. Correlation with the new international zonation based on the appearance and spread of genera (House and Kirchgasser, 1993; Becker and others, 1993; Becker, 1993b) is straightforward, although there are regional features mirroring local facies developments. For example, international marker genera such as Trimanticoceras, Carinoceras, Neomanticoceras and Playfordites are still lacking in the Montagne Noire area. Late Middle Frasnian beds at Coumiac, below the equivalent of the Lower Kellwasser Limestone (Bed 24a), contain Beloceras, various manticoceratids and somewhat ambiguous Costamanticoceras (House and others, 1985; pl. 2, figure 11-12). The latter is a marker for the Playfordites and Neomanticoceras Genozones (do I-I and I$\mathrm{J}$ ), or for the cordatum Zone (do IB/y) of the classical goniatite zonation. Index species for Divisions I-K so far have only been found above the Lower Kellwasser level in Bed 25b (Archoceras sp.) and Bed 26b (Manticoceras adorfense). The first evidence for the latest Frasnian Crickites Genozone (do I-L) comes from Bed 26c. At Coumiac and neighbouring sections of the Mont Peyroux Nappe a succession of Crickites species can possibly be established. All early, often somewhat doubtful members of the lineage have whorl forms similar to Manticoceras cordatum and may be related to the Canadian Crick. cordiforme (Miller). Crick. holzapfeli, the index species of the classical holzapfeli Zone, enters in great profusion in the lower part of Bed 3le and continues to Bed $31 \mathrm{~g}$ and to the end of the Frasnian. The apparent patchiness of the Upper Frasnian goniatite record is only to a limited extent a consequence of sampling bias. Clearly two different goniatite assemblages alternate with each other. The first is characterized by great abundance of Beloceras tenuistriatum (e.g. in Beds $26 \mathrm{~d}$ and 31 a) and rarity of gephuroceratids and tornoceratids. Other beds have rich Manticoceras or Crickites faunas accompanied by more abundant tornoceratids, and Buchiola. Due to the lack of lithological differences between beds containing the two faunal types it is inferred that changing assemblages mirror fluctuations in the trophic structure. Especially the Upper Kellwasser Limestone equivalents with their rich Crickites and pelecypod faunas associated with unusually large ostracods but without Beloceras may have been deposited under eutrophic ecological conditions. This suggests that beloceratids thrived during oligotrophic periods.

The chosen stratotype has one of the best known goniatite records around the Frasnian/Famennian boundary and is the best known anywhere for index species occurring in beds exactly at the boundary. However, it is far from being an ideal ammonoid locality due to aspects of preservation and difficult recovery of large faunas. This misfortune can partly be balanced by the wide range of other goniatite-bearing and easily correlatable localities nearby in the Montagne Noire, which supply additional information on stratigraphical ranges and occurrences in slightly different facies settings. These will be documented elsewhere (Becker and House, 1994 in press).

\section{Trilobites}

Among bottom-living biotas, trilobites are most frequent and diversified in the Late Frasnian strata at Coumiac. Of eight families

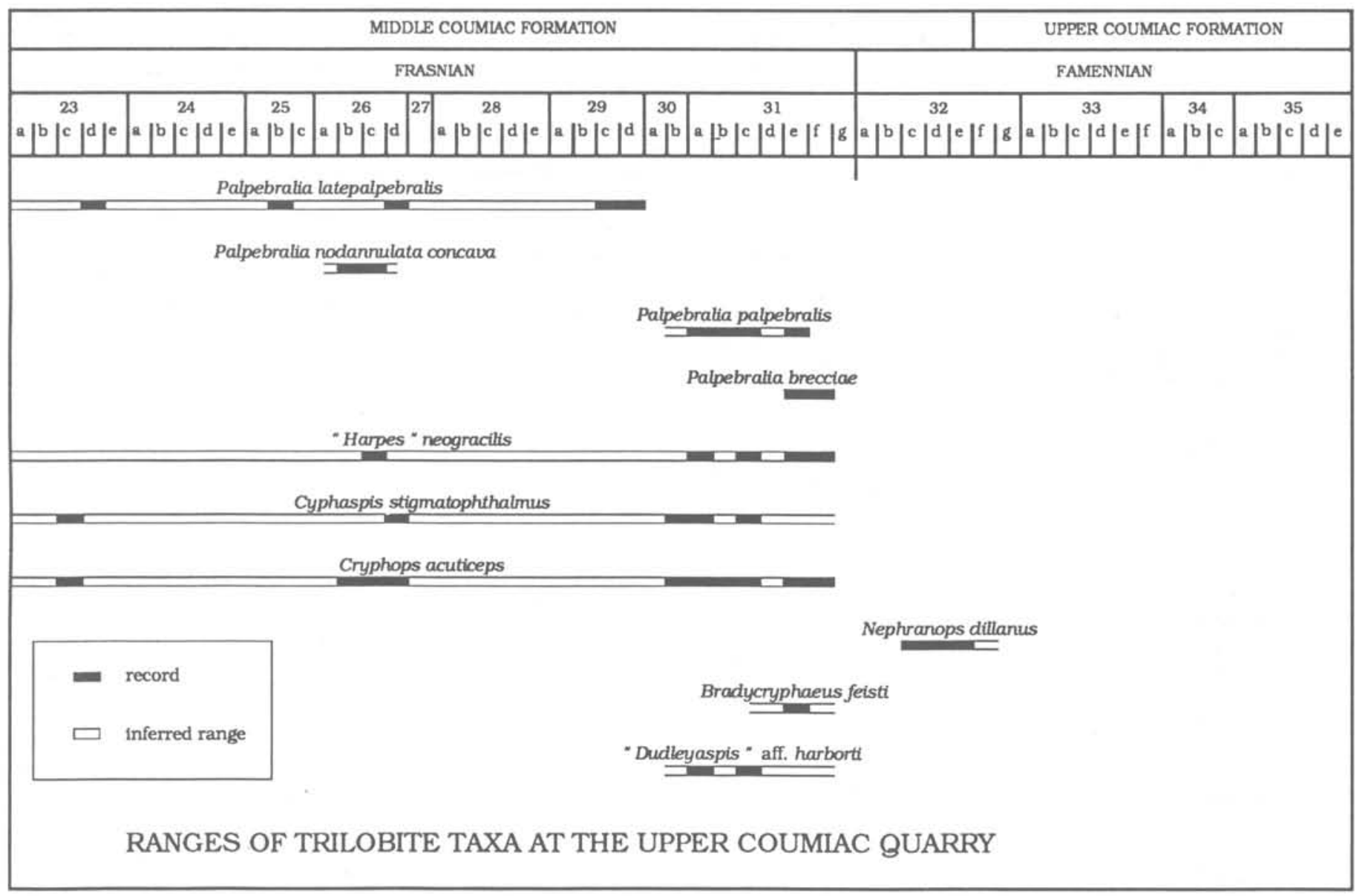

Figure 7 Range chart showing the trilobite record from Bed 23 to Bed 39 around the GSSP in the section at the Upper Quarry at Coumiac. Modified from data of R Feist (in Feist, 1990). 
known globally to be present at the Upper Kellwasser extinction event (Feist, 1990); 1991), six occur in the stratotype section (Proetidae, Aulacopleuridac. Odontopleuridae, Harpetidae, Dalmanitidae and Phacopidae) and of a total of 13 species known globally, nine are represented at Coumiac (see figure 7). All but three families and all species disappear within Zone 13, or at the base of the Upper Kellwasser Limestone equivalent (Bed $3 / \mathrm{g}$ ). The latter does not yield any trilobites, nor do the succeding beds of the Lower triangularis Zone (Bed 32a-b), a fact which has been observed in all known Frasnian/ Famennian boundary sections world wide. Recovery does not take place earlier than from the Middle triangularis Zone onwards when solely phacopids of the genus Nephranops occur (Beds 32c-e). Thus the defined basal Famennian at the base of the Lower triangularis Zone, cannot be precisely recognised using trilobites. By contrast. the base of the topmost Frasnian Kellwasser Limestone level can be located with considerable precision by the major extinction affecting trilobites at that level (Feist and Schindler, 1994).

Fine-scale intrazonal subdivision and biostratigraphical correlation of the latest Frasnian at Coumiac is provided by evolutionary species of the proetid Palpehralia which are characterized by a trend in reduction of the palpebral lobe and in the straightening of the facial sutures. The ancestral form, Pal. latepalpebralis being already present below the Lower Kellwasser Limestone equivalent (Bed 24a), has been recovered as high as in the middle of Zone 13 (Bed 29 d). It gave rise to Pal. palpebralis which is abundant in Beds 31 a to $31 \mathrm{e}$ and is also known from latest Frasnian sections in the Rhenish Schiefergebirge and Harz (Feist and Schindler, 1994) and may occur in the Canning Basin of Western Australia (K McNamara oral communication) The last representative of the lineage is $P$ al. brecciac which enters the stratotype section in Bed $31 \mathrm{c}$ and $\mathrm{f}$, thus marking precisely the last oxygenated level-bottom environment prior to the hypoxic overturn of the Upper Kellwasser Limestone. This species is at least of moderate value for long distance correlation as it has been recovered in the Rhenish Schiefergebirge (at Steinbruch Schmidt) and in the Harz (Aeke Valley) in an equivalent position and associated there with Palmatolepis linguiformis (Schindler, 1990). Consequently Pal. brecciae appears to be limited to the lower part of the linguiformis Zone. This supports the results obtained by graphic correlation, which indicated the presence of linguiformis Zone equivalents at Coumiac in Beds $31 \mathrm{f}$ and $\mathrm{g}$ (Klapper in Becker and others, 1989, p. 262).

Concomitantly with the Palpebralia line, another evolutionary trend is seen in succeeding populations of Cryphops acuticeps and this trend is of biostratigraphical significance. This group, which is rather common in Beds 31 a to $31 \mathrm{f}$, exhibits a spectacular reduction in the mean number of its eye lenses which drop from ten lenses in Bed 31 a to only three lenses in Bed $31 \mathrm{f}$ before its final extinction (Feist, 1991). This evolution may represent a further potential for fine-scale biostratigraphical subdivisions and correlation during a period of world-wide biotic crisis.

\section{Other fossil groups}

Palynomorphs have been obtained from the Upper Kellwasser level (Bed $3 \mathrm{lg}$ ) but are too badly preserved for precise identification: further work is required here. The stratigraphically important entomozoaceans are a rather minor faunal element; detailed work is currently being carried out by $F$ Lethiers. Solitary rugose corals, gastropods, orthoconic and breviconic nautiloids, crinoids and rare fish scales represent further accessory fossil groups still to be investigated in detail. Brachiopoda and bivalve records of $\mathrm{C}$ Babin and $\mathrm{PR}$ Racheboeuf have been presented (in Feist, 1990). Rich homoctenid faunas have been determined by $M$ Truyols-Massoni (in Feist, 1990); the Homoctenus ultimus Zone is first recognized in Bed $26 \mathrm{c}$ and therefore seems to correlate with the Crickites Genozone. Ostracod data of F Lethiers have been listed (in Feist, 1990), and more than 30 different species are recognised in the topmost beds of the
Frasnian; among the benthonic forms, the Frasnian/Famennian boundary is characterized by a major extinction since 65 per cent of all recorded taxa disappear there (Lethiers and Feist, 1991). Thus, the Coumiac stratotype bears evidence of an extraordinary breadth of faunal representation enabling correlation into regimes with better spore and acritarch records. The SDS views this documentation as the best of any of the levels it has recommended for boundary stratotypes in the Devonian.

\section{Chemostratigraphy}

As yet geochemical methods do not provide an unambiguous guide to correlation internationally, although there is great potential especially with strontium isotope chemostratigraphy applied within the framework of conodont biostratigraphy (e.g. Ruppel and others. 1993). Geochemical methods do, however, provide an important clue to environmental interpretation. The stratotype section at Coumiac has been investigated for $\delta^{13} \mathrm{C}^{12} \mathrm{C}$ values by Joachimski and Buggisch (1993) where a positive shift of $\sigma^{13} \mathrm{C}$ was noted at the boundary. Rare-earth elements (REE) have been investigated by Grandjean-Lécuyer and others (1993) using individual Devonian conodonts. but no anomaly at the boundary was noted although the REE patterns did not conform with those of modern sea water. The pursuit of iridium anomalies has not been successful at Coumiac (Girard and others, 1993), nor at Steinbruch Schmidt (McGhee and others, 1984). Those claimed at the boundary in the Canning Basin have proved to be from a much higher stratigraphic level (Becker and others, 1991; Nicoll and Playford, 1993) although there is a weak iridium anomaly apparently at the correct level at Xiangtian (Wang and others, 1991) and other element anomalies, but the cause is uncertain. There has been no link of microtektites with the boundary stratotype and records elsewhere are higher in the Famennian (high within the Lower riangularis Zone at Senzeilles in Belgium: Claeys and others. 1992. ligure 1; Lower crepida Zone in south China: Wang, 1992).

\section{Relationship to the Upper Kellwasser Event}

The main sedimentary marker of the GSSP is the top of the distinctive level known in Germany as the Upper Kellwasser Limestone (Walliser and others (1989). This dark hypoxic limestone appears to represent an acme in the spread of a distinctive facies which in many sections globally is precisely constrained by conodont biostratigraphy. In parallel with the work of the SDS in recent years has been the recognition of an important extinction event near the Frasnian/Famennian boundary. Some of these extinctions were listed in the previous sections. The recommendation of the Subcommission for a GSSP falls at a level immediately above the acme of extinctions, that is at the base of the Lower triangularis Zone. The most precise documentation for this (Becker and others, 1989) has been followed by data assembled for the Subcommission and illustrated here (figures 5-7). Following especially the work of Sandberg and others (1988) this level has been widely traced internationally.

There has been much debate on the cause of the sedimentary perturbation represented by the Upper Kellwasser Limestone. The matter cannot be said to be resolved. Indeed, some members of the Subcommission earlier took the view that a more appropriate boundary might be chosen away from the sudden faunal and sedimentary change just below the base of the Lower triangularis Zone but in the end, the ease of international correlation based on the faunal changes led to this boundary being recommended.

Four main groups of hypotheses have been invoked to explain the faunal and sedimentary changes around the base of the Lower triangularis Zone. Firstly, causes related to a bolide impact or impacts (Sandberg and others 1988, Mclaren and Goodfellow 1990). Secondly, a spread of anoxic conditions on continental shelves associated with possible tectonic events and ocean overturn (Wilde and 
Berry, 1984; Buggisch, 1991) with a transgression followed by quick regression at the upper boundary (Sandberg and others, 1988). Thirdly, these second events but associated with a peak of cold climatic conditions, resulting in a rise of the pycnocline (Copper, 1986). Fourthly, the same, but with the Upper Kellwasser Limestone representing a peak of hot climatic conditions, resulting also in a rise of the pycnocline and probable disruption of the trophic tiering, particularly that of the plankton (Becker and House, 1994); this latter theory was first invoked for Devonian anoxic events by Becker (1992). Related hypotheses involving climatic warming have been suggested by Thompson and Newton (1989) and Ormiston and Klapper (1992). It is generally recognised that the collapse of stromatoporoid reef systems near the end of the Irasnian led to extinctions of associated faunas. House (1985) has drawn attention to the many similar events at other levels in the Devonian suggesting that an interpretation enabling a common hypothesis is to be preferred.

Whatever the cause(s) of this sedimentary perturbation may be. the SDS took the view that the hypoxic perturbations below the base of the Lower triangularis Zone resulted in a considerable faunal changeover and an horizon which may be correlated internationally with perhaps more precision than any other in the Devonian. It is in the light of this view that Coumiac was recommended for the GSSP to define the base of the Famennian Stage.

\section{References}

Becker, R T, 1992, Zur Kenntnis von Hembere-Stufe und Annulatia Schicfer im Nordsauerland (Oberdevon. Rheinisches Schicfergebirge, GK 4611 Hohenlimburg): Berliner Geowissenschaftliche Abhandlungen E. v. 3(1). pp. 3-41

Becker, R T, 1993a, Stratigraphische Glicderung und AmmonoideenFaunen im Nehdenium (Oberdevon II) von Europa und Nord-Afrika: Courier Forschungsinstitut Senckenberg. v. 155, 405 pp.

Becker, R T, 1993b, Anoxia. custatic changes, and Upper Devonian to lowermost Carboniferous global ammonoid diversity, in House, M R, ed.. The ammonoideat enviromment, ccology, and evolutionary change: Systematics Association special v. 47, Clarendon Press, Oxford, pp. $115-163$.

Becker. R T. Feist. R, Flajs. G, House, M R, and Klapper, G, 1989 , Irasnian/Famennian extinction events in the Devonian at Coumiac, southern France: Comples Rendus de l'Académie des Sciences, Paris, Ser. II, v. 309, pp. 250-266.

Becker. R T, and House. M R, 1994, Kellwasser events and goniatite suecessions in the Montagne Noire with comments on possible causations: Courier Forschungsinstitut Senckenberg. v. 169, pp. 45-77.

Becker, R T. House, M R, and Ashouri, N-R, 1988, Potential stratotype section for the Frasnian/Famennian boundary at El Atrous. Tatilalt. Moroces: Document submitted to the International Subconmission on Devonian Stratigraphy, Rennes, 1988.6 pp.

Becker, R T. House, M R, Kircheasser, W T, and Playford, P E, 1991, Sedimentary and faunal changes across the Frasnian/Famennian boundary in the Canning Basin of Western Australia: Historical Biology, v. 5, pp. 183-196.

Becker, R T, House, M R. and Kirchgasser, W T, 1993, Devonian goniatite biostratigraphy and timing of lacies movements in the Frasnian of the Canning Basin, Westem Australia, in Hailwood, E A, and Kidd, R B, eds., High resolution stratigraphy: Geological Society Special Publication, no, 70, pp. 29.3-321.

Branson, E B, and Mehl. M G, 1934, Conodonts from the Grassy Creek Shale of Missouri: University of Missouri Studies, v. 8, 171-259 |imprint 19331.

Buggisch, W, 1991, The global Frasnian/Famennian 'Kellwasser Event' Geologische Rundschau, v. 80/1, pp. 49-72.

Bultynck, P. Dreesen, R, Groessens, E, Struve, W, Weddige, K, Werner, R, and Ziegler, W, 1988, Ardennes (Belgium) and lïfel Hills (Federal Republic of Germany): Courier Forschungsinstitut Senckenberg, v. 102. pp. $9-155$

Clacys, P, Casier, J-G, and Margolis, S, V. 1992, Mikrotectites and mass extinctions: evidence for a Late Devonian asteroid impact: Science, v. 257. pp. $1102-1104$.

Copper, $\mathbf{P}, 1986 \mathrm{Frasnian/Famennian} \mathrm{mass} \mathrm{extinction} \mathrm{and} \mathrm{cold-water}$ occans: Geology, v. 14. pp. 835-839.
Feist, R, ed., 1990, The Frasnian/Famennian boundary and adjacent strata of the eastern Montagne Noire, France: IUGS Subcommission on Devonian Stratigraphy, Guide Book, $69 \mathrm{pp}$.

Feist, R. 1991, The late Devonian tillobite crisis: Historical Biology, v. 5, pp. $197-214$

Feist, R, and Schindler, E. 1994, Trilobiles during the Frasnian Kellwasser crisis in European Lite Devonian cephalopod limestones: Courier Forschungsinstitut Senckenberg, v. 169, 195-223.

Girard, C. Rocehia, R, Feist, R, Froget, L, and Robin, E. 1993, No evidence of impact at the Frasnian/Famennian boundary in the stratotype area, southern Irance: Interdisciplinary Conference on Global Boundary Events, Kielce, 27-29 September 1993. Abstract.

Goodfellow, W D. Geldsetzer. H H J, McLaten. D J. Orchard. M J, and Klapper, G, 1989, The Frasnian/Famennian extinction: current results and possible causes, in McMillan. N J, Finbry, A F and Glass. D J, cds., Devonian of the World: Canadian Society of Petroleum Geologists, Memoir 14, v. 3, pp. 9-21.

Grandjean, P, Albarede, F, and Feist, R, 1989, REE variations across the Frasnian/Famennian boundary: Terra Abstracts, v. 1, pp. 184

Grandjean-Lécuyer, P, Feist. R, and Albarède, F, 1993, Rare earth elements in old biogenic apatites: Geochemicat et Cosmochemicat Actat v. 57. pp. $2507-2514$.

House, M R. 1985. Correlation of mid-Palaeozoic ammonoid cvolutionary events with global sedimentary perturbations: Nature. London. v. 313. pp. 17-22.

House, M R, and Kirchgasser, W T, 1993. Devonian goniatite biostratigraphy and timing of facies movements in the Frasnian of eastern North America, in Hailwood, E.A. and Kidd, R B. cds.. High Resolution Stratigraphy, Geological Society Special Publicition, no. 70, London, pp. 267-292.

Housc, M R, Kirchgasser, Price, J D, and Wade, G, 1985, Goniatites from Frasnian (Upper Devonian) and adjacent strata of the Montagne Noire: Hercynica, v. 1, pp. 1-19.

Ji, Q, 1989, On the Frasnian/Fannennian mass extinction event in South China: Courier Forschungsinstitut Senckenberg, v. 117, pp. 275-301.

Joachimski. M M. and Buggisch. W, 1993, Anoxic events in the late Frasnian - Causes of the Frasnian/Famennian faunal crisis: Geology, $v$ 21. pp. 675-678.

Klapper. G, 1989. The Montagne Noire Frasnian (Upper Devonian) conodont succession, in McMillan. N J, Fimbry, A F and Glars, D J. eds., Devonian of the World: Canadian Sociely of Petroleum Genlogists, Memoir 14, v. 3. pp. 449-468.

Klapper, G. and Foster Jr, C T, 1993, Shape analysis of Frasnian species of the Late Devonian conodont genus Palmatolepis: Palcontological Socicty. Mcmoir 32 (Journal of Palcontology, v. 67, no. 4, supp.), 35 pp.

Lethiers, F, and Feist, R, 1991, lat crise des ostracodes benthicuess au passage Frasnicn-Famennian de Coumiac (Montagne Noire, France méridionale): Comptes Rendus de l'Académie des Sciences. Parriss. Sor. II, v. 312, pp. 1057-1063.

Mc Ghee Ir, G R, Gilmore, J S, Orth, C J, and Olsen, E, 1984. No geochemical evidence for an asteroidal impact at late Devonian mass extinction horizon: Nature, London, v. 308, pp. 629-631.

McL aren, D J, and Goodfellow, W D, 1990), Geological and biological consequences of giant impacts: Annual Review Earth and Planetary Sciences. v. 18. pp. 123-171.

Nicoll. R S, and Playford, P E. 1993. Upper Devonian iridium anomalies. conodont zonation and the Frasnian/Famennian boundary in the Canning Basin. Western Australia: Palaeogeography, Palaeclimatology, Palaecocology, $、 104$. pp. $105-113$.

Ormiston, A R, and Klapper, G, 1992. Palcoclimate, controls on Upper Devonian source rock sequences and stacked extinctions: 5th North American Paleontological Convention, Abstracts and Program. Paleontological Society Special Publication no. 6, p. 227.

Ruppel, S C, James, E W, and Barrick, J E, 1993, High resolution strontium isolope chemostratigraphy of the Paleozoic using conodonts: (joological Society of America, Abstracts with Programs, v. 25(6), pp). A47.3-474

Sandberg, C A, Schindler, E, Walliser, O H, and Ziegler. W, 1990, Proposal for the Erasnian/Famennian at Steinbruch Schmidt (Ense area, Kellerwald, Rhein. Schiefergebirge, Germany) and matcrial for the corresponding tield trip on Scptember 18, 1990. Document (unpublished) submitted to the Subcommission on Devonian Stratigraphy (ICS, IUGS), Frankfurt/M, $18 \mathrm{pp}$.

Sandherg, C A, Ziegler, W, Dreesen, R, and Butler. J L, 1988, Late Frasmian mass extinction: Conodont cvent stratigraphy. global changes and possible causes: Courier Forschungsinstitui Senckenberg, v. 102, pp. 26.3-307. 
Sannemann, D, 1955, Beitrag zur Untergliederung des Oberdevons nach Conodonten: Neues Jahrbuch für Geologie und Paläontologie, Abhandlungen, v. 100(3), pp. 324-331.

Schindler, E, 1990, Die Kellwasser-Krise (hohe Frasne-Stufe, Oberdevon): Göttinger Arbeiten zur Geologie und Paläontologie, v. 46, $115 \mathrm{pp}$.

Scrutton, C T, 1988, Patterns of extinction and survival in Palaeozoic corals: Systematics Association Special Volume no. 34, pp. 65-88.

Sorauf, J E, and Pedder, A E H, 1986, Late Devonian rugose corals and the Frasnian/Famennian crisis: Canadian Journal of Earth Science. v. 23, p. $1265-1287$.

Stearn, C W, 1987, Effect of the Frasnian/Famennian extinction event on stromatoporoids: Geology, v, 15, pp. 677-679.

Thompson, J B, and Newton, C R, 1989, Late Devonian mass extinction: episodic climatic cooling or warming? in McMillan, N J, Embry, A F and Glass, D J, eds., Devonian of the World: Canadian Society of Petroleum Geologists, Memoir 14, v. 3, pp. 29-34.

Vanguestaine, M, DeClairfayt, T, Rouhart, A, and Smeesters, A, 1983. Zonation par acritarchs du Frasnien Supérieur-Fanmennian Inférieur dans les bassins de Dinant, Namur, Herve et Campine (Dévonien Supéerieur de Belgique): Annales Société géologique de Belqique, v. 106, pp. 121-171.

Dr Gilbert Klapper (top right) is Professor of Geology at the University of Iowa, Iowa City, Iowa 52242, USA. His research concentrates on Silurian and Devonian conodont taxonomy and biostratigraphy, with special emphasis on the Frasnian. He is currently involved with methods of morphometric analysis of conodonts and their use in graphic correlation. He is a Titular Member of the Subcommission on Devonian Stratigraphy and was its Vice-Chairman from 1976 to 1984.

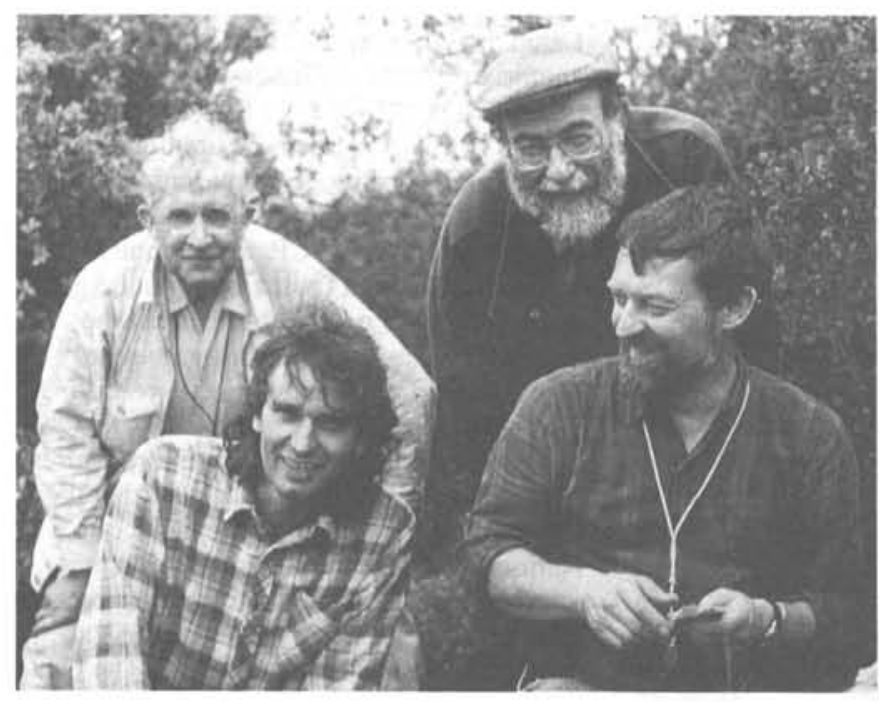

Walliser, O H, Groos-Uffenorde, H, Schindler, E, and Ziegler, W, On the Upper Kellwasser Horizon (Boundary Frasnian/ Famennian): Courier Forschungsinstitut Senckenberg, v. 110, pp. 247-255.

Wang, K, 1992, Glassy microspherules (microtektites) from an Upper Devonian limestone: Science, v. 256, pp. 1547-1550.

Wang, K, Orth, C J, Attrep Jr, M, Chatterton, B D E, Hongfei, H, and Geldsetzer, H H J, 1991, Geochemical evidence for a catastrophic biotic event at the Frasnian/Famennian boundary in south China: Geology, v. 19, pp. 776-779.

Wilde, P, and Berry, W B N, 1984, Destabilization of the oceanic density structure and its significance to marine 'extinction' events: Palaeogeography, Palaeoclimatology, Palaeoecology, v. 48, pp. 143-162.

Ziegler. W. 1962. Taxionomie und Phylogenie Oberdevonischer Conodonten und ihre stratigraphische Bedeutung: Abhandlungen des Hessischen Landesamtes für Bodenforschung, v. 38, 166 pp.

Ziegler, W, 1971, Conodont Stratigraphy of the European Devonian: Geological Society of America Memoir 127, pp. 227-284.

Ziegler, W, and Sandberg, C A, 1990, The late Devonian conodont zonation: Courier Forschungsinstitut Senckenberg, v. 121 , $115 \mathrm{pp} \square$

Dr Raimund Feist (bottom right) is Director of Research with the French National Scientific Research Centre (CNRS) at the University of Montpellier (USTL, 34095 Montpellier. France). His research concentrates on north-Gondwanan trilobite geography, systematics and biostratigraphy. He is currently analysing the impact of global events on late Devonian outer shelf trilobite biofacies, evolution and diversity. He is Vice-Chairman of the Subcommission on Devonian Stratigraphy.

Dr $R$ Thomas Becker (bottom left) works at the Palaeontological Institute of the Free University Berlin (Malteserstraße 74-100, Building D, 12249 Berlin). He received his doctorate in 1991, from the Ruhr-University of Bochum, Germany. From 1988 to 1990 he worked at the University of Southampton on Devonian extinction events. His research concentrates on Middle Palaeozoic ammonoids, high-resolution stratigraphy, sea-level fluctuations and the links between global environmental change and evolution in the Devonian. He is a Corresponding Member of the Subcommission on Devonian Stratigraphy.

Professor Michael R House (top left) is Professor of Geology at the University of Southampton (Southampton SO9 5NH, UK) and formerly of the University of Hull. He is a former President of the Palaeontological Association, the Systematics Association and Palaeontographical Society. His researches have mainly concentrated on mid-Palaeozoic international correlation and regional and event synthesis, mainly using ammonoids. He is currently Chairman of the Subcommission on Devonian Stratigraphy.

Episodes

\section{A reminder of our address changes, please tell your colleagues and friends.}

For editorial matters contact:

The Editor, Episodes

British Geological Survey

Keyworth

Nottingham NG12 5GG

United Kingdom
For subscription matters contact:

Episodes

Computer Posting Group

120-126 Lavender Avenue

Mitcham

Surrey CR4 3HP

United Kingdom 